\title{
Hypoxic Stress Exacerbates Hyperoxia- Induced Lung Injury in a Neonatal Mouse Model of Bronchopulmonary Dysplasia
}

\author{
Veniamin Ratner $^{\mathrm{a}}$ Siarhei Slinko $^{\mathrm{a}}$ Irina Utkina-Sosunova ${ }^{\mathrm{a}}$ Anatoly Starkov ${ }^{\mathrm{b}}$ \\ Richard A. Polin ${ }^{\mathrm{a}}$ Vadim S. Ten ${ }^{\mathrm{a}}$ \\ ${ }^{a}$ Department of Pediatrics, Columbia University College of Physicians and Surgeons, and \\ ${ }^{b}$ Department of Neurology, Weill College of Medicine, Cornell University, New York, N.Y., USA
}

\section{Key Words}

Bronchopulmonary dysplasia $\cdot$ Hypoxia $\cdot$ Hyperoxia $\cdot$ Lung injury $\cdot$ Oxidative stress $\cdot$ Glutathione $\cdot$ Protein carbonyls

\begin{abstract}
Background: Premature infants with lung injury often experience intermittent episodes of hypoxemia. Objective: This study investigates whether intermittent hypoxemia exacerbates oxidative stress and lung injury in neonatal mice in a hyperoxia-induced model of bronchopulmonary dysplasia (BPD). Methods: For the BPD model, 3-day-old C57BI/6J mice were exposed to hyperoxia $\left(65 \% \mathrm{O}_{2}\right)$ for 4 weeks $\left(\mathrm{O}_{2}\right.$ group $)$ or to hyperoxia and intermittent (10 min daily) hypoxia $\left(\mathrm{O}_{2}+\right.$ $\mathrm{H}$ group). Upon completion of $\mathrm{O}_{2}$ or $\mathrm{O}_{2}+\mathrm{H}$ exposure, the degree of pulmonary alveolarization and granulocytic infiltration were examined. The severity of oxidative injury in lungs was defined by tissue glutathione and protein carbonyl content. Data were compared to those in naïve mice and mice subjected only to intermittent hypoxia. Results: Hyperoxiaexposed mice exhibited a dramatic $(p<0.0001)$ decrease of alveolarization, significantly increased granulocytic infiltration $(p<0.0001)$ and increased protein carbonyl content ( $p=0.04)$ compared to naïve mice. However, $\mathrm{O}_{2}+\mathrm{H}$ mice demonstrated significantly $(p=0.03)$ fewer alveoli compared
\end{abstract}

to their $\mathrm{O}_{2}$ counterparts. This was associated with a significantly $(p=0.02)$ decreased pulmonary total/oxidized glutathione ratio and a significant $(p=0.03)$ elevation of protein carbonyl content. Conclusions: Thus, intermittent hypoxic stress during hyperoxic induction of BPD in mice potentiates oxidative stress in lung tissue and exacerbates alveolar developmental arrest.

Copyright $\odot 2008$ S. Karger AG, Basel

\section{Introduction}

Bronchopulmonary dysplasia (BPD) is a leading cause of morbidity and mortality among premature neonates [1]. Over the past 2 decades, the histological presentation of BPD has changed from heterogeneous pulmonary inflammation and fibrosis to uniform arrest of alveolar development [2]. Oxidative stress induced by exposure to supraphysiological concentrations of oxygen $\left(\mathrm{O}_{2}\right)$ is one of the proposed mechanisms of alveolar developmental arrest in BPD [3-5]. It has been shown that exposure to hyperoxia or hypoxia results in increased accumulation of reactive oxygen species (ROS) in lung tissue $[6,7]$. To prevent oxidative injury, organisms have evolved different antioxidant systems (superoxide dismutase, catalase,

\section{KARGER}

Fax +41613061234 E-Mail karger@karger.ch www.karger.com
Veniamin Ratner, MD

Division of Neonatal-Perinatal Medicine, Department of Pediatrics

Columbia University, 630W 168th Street P\&S 3-440

New York, NY 10032 (USA)

Tel. +1 212342 0503, Fax +1 212305 7086, E-Mail vr158@columbia.edu 
glutathione peroxidase and various thio-, peroxi- and glutaredoxins). Glutathione is viewed as the key component of all antioxidant defenses [8].

Premature infants are known to experience intermittent episodes of hypoxemia lasting from a few seconds to several minutes [9]. Furthermore, infants who develop BPD experience more frequent episodes of $\mathrm{O}_{2}$ desaturations than infants who recover from respiratory distress syndrome without developing BPD [10, 11]. Given that intermittent hypoxia has been shown to exert oxidative stress $[12,13]$, we hypothesized that intermittent hypoxemia exacerbates oxidative stress, which results in more severe lung injury in mice with hyperoxia-induced BPD.

\section{Materials and Methods}

\section{The BPD Model and Study Design}

BPD in neonatal mice was produced as we described previously [14]. Three-day-old (p3) C57Bl/6J mice of both genders were purchased from Jackson Laboratories (Bar Harbor, Me., USA). p3 mice are at the saccular stage of their lung development, which corresponds to lung development in the human fetus at 28-30 weeks of gestation [15]. Pups from different litters were randomly distributed between dams (6 pups per dam) to minimize a litterdependent bias. Body weights prior to and after completion of BPD modeling were recorded. The experimental protocol was approved by the Columbia University Institutional Animal Care and Use Committee. Briefly, p3 mice were exposed to $65 \% \mathrm{O}_{2}$ for 4 weeks by constant delivery ( 0.5 liters $/ \mathrm{min}$ ) of $100 \% \mathrm{O}_{2}$ into a custom-made $1.2-\mathrm{m}^{3}$ plastic chamber to maintain the fraction of inspired oxygen at $0.65 \pm 0.03$. The $\mathrm{O}_{2}$ concentration inside the chamber was constantly monitored. Hyperoxia exposure was interrupted for 10 min daily to clean the cages and exchange dams between experimental and naïve (not exposed to $\mathrm{O}_{2}$ ) mice in order to minimize any adverse effect of hyperoxia on milk production by the dams.

To mimic desaturation episodes in premature infants requiring $\mathrm{O}_{2}$ therapy, randomly selected mice were exposed to brief ( 10 $\mathrm{min}$ ) intermittent hypoxic stress during the course of hyperoxia. The hypoxic stress consisted of exposure to $8 \% \mathrm{O}_{2}\left(\mathrm{~N}_{2}\right.$ balanced) daily for 1 week and every other day for another week. Each mouse was exposed to the total of 10 hypoxic episodes. The timing for hypoxic exposure (first 2 weeks of life) was chosen because mouse lungs go through the saccular and early alveolar stages of development during the first 2-3 postnatal weeks [15]. Given that the pathological hallmark of BPD in human neonates is alveolar developmental arrest, hypoxic challenges were applied during this vulnerable period of alveolar formation. During the hypoxic challenge, the $\mathrm{O}_{2}$ saturation and heart rate were monitored in randomly selected mice using pulse oximetry (Nonin Medical Inc., Plymouth, Minn., USA). The duration of hypoxic episodes was limited to $10 \mathrm{~min}$, because during this period of time, animals demonstrated $\mathrm{O}_{2}$ desaturation (oxygen saturation $=60 \pm 3.26 \%$ ) without bradycardia.
The following experimental groups were studied (fig. 1a):

(1) Hyperoxia $\left(\mathrm{O}_{2}\right)$ group $(\mathrm{n}=10)$ : mice were exposed to hyperoxia alone without hypoxic challenge. This group was designed to model BPD.

(2) Hyperoxia + hypoxia $\left(\mathrm{O}_{2}+\mathrm{H}\right)$ group $(\mathrm{n}=15)$ : mice were exposed to $65 \% \mathrm{O}_{2}$ for 4 weeks and subjected to hypoxic stress during the first 2 weeks of hyperoxia. This group was designed to mimic infants who experience brief episodes of desaturations at the initial stage of BPD development.

(3) Normoxia + hypoxia $(\mathrm{NH})$ group $(\mathrm{n}=10)$ : mice were subjected to intermittent hypoxic stress during the first 2 weeks of life. This group was designed to discriminate the impact of intermittent hypoxia from that of combined hyperoxic/hypoxic stress on the alveolar development.

All data obtained from experimental groups were compared to those of age-matched normoxic naïve mice $(n=5)$ that were not exposed to hyperoxia or hypoxia.

Upon completion of BPD modeling, the severity of lung injury was defined by histopathological evidence of alveolar developmental arrest.

\section{Pulmonary Histopathology}

At 4 weeks of age, anesthetized mice were sacrificed by thoracotomy and transection of the thoracic aorta. Lungs were perfused with phosphate buffer solution with EDTA. Following perfusion, lungs were filled via the trachea with the same buffer solution under pressure of $20 \mathrm{~cm} \mathrm{H}_{2} \mathrm{O}$ for $5 \mathrm{~min}$. The right lung was snap frozen in liquid nitrogen and processed for measurement of glutathione and protein carbonyl content. The left lung was fixed in $4 \%$ paraformaldehyde and embedded in paraffin. Five-micrometer sections (100 $\mu \mathrm{m}$ apart) were obtained from the anterior, middle and posterior frontal planes and stained with hematoxylin and eosin.

Radial Alveolar Count. The degree of alveolarization was defined by the radial alveolar count (RAC) $[16,17]$. Briefly, an investigator 'blinded' to the study groups performed RACs during examination of digital images captured under identical magnification. The RAC was the number of distal air sacs that were transected by the line drawn perpendicular from the most proximal to the pleura terminal bronchiole toward the nearest pleura. Three RACs were obtained from each section (9 RACs for each mouse). The mean value of all RACs for each mouse was used for statistical analysis.

Immunohistochemistry. Detection of Ly6G/C antigen-positive cells (granulocytes) in lung tissue was used as a marker of inflammatory cell infiltration. Initially, $5-\mu \mathrm{m}$ sections were blocked with appropriate secondary antibody serum. Then, specimens were incubated overnight at $4^{\circ} \mathrm{C}$ with primary rat antimouse Ly6G/C monoclonal antibodies (BD Bioscience, San Jose, Calif., USA). Following incubation with secondary goat antirat Alexa Fluor-conjugated antibodies (Invitrogen, Carlsbad, Calif., USA), sections were examined using a Bio-Rad 2000 confocal microscope. To analyze the degree of pulmonary granulocytic infiltration, Ly6G/C-positive cells were 'blindly' counted in 9 nonadjacent areas [ 3 areas per section, 3 sections (anterior, middle and posterior) per mouse] captured under identical magnification and fluorescence. The mean number of Ly6G/C-immunopositive cells per square millimeter of pulmonary tissue for each animal was used for data analysis. 
Markers of Oxidative Stress and Injury in Lungs

The oxidative lung injury was defined as follows: (1) as an increase in the tissue content of products of molecular oxidative damage, i.e. protein carbonyls (products of protein oxidation), coupled with (2) assessment of the tissue antioxidative capacity, i.e. total/oxidized glutathione ratio. Briefly, following homogenization, lung tissue samples were centrifuged for $2 \mathrm{~min}$ at $10,000 \mathrm{~g}$. The supernatant was used for the measurement of pulmonary total and oxidized glutathione and protein carbonyl content. Total protein concentration in the lung tissue was determined according to the method of Bradford [18].

Measurement of Protein Carbonyls. Protein carbonyl content in the lung tissue was determined spectrophotometrically at 340 $\mathrm{nm}$ using a protein carbonyl assay kit (Cayman Chemical Co., Ann Arbor, Mich., USA). The protein carbonyl concentration was expressed as nanomoles per gram of total protein.

Measurement of Glutathione. Total (reduced plus oxidized) and oxidized tissue glutathione concentrations were measured as described by Griffith [19] with minor modifications. Briefly, to prevent self-oxidation, tissue samples were diluted in 5\% metaphosphoric acid (1:1). Three working solutions were used: (1) 0.3 mM NADPH (Sigma-Aldrich, St. Louis, Mo., USA), (2) 6 mM 5, 5' dithiobis-2-nitrobenzoic acid (Sigma-Aldrich) and (3) $10 \mathrm{U} / \mathrm{m}$ glutathione reductase (Sigma-Aldrich). Reduced glutathione at concentrations of 0 to $20 \mu \mathrm{M}$ was used as standard (Sigma-Aldrich). The total glutathione concentration was measured at 405 $\mathrm{nm}$ using a microplate reader (Tecan, Männedorf, Switzerland). To measure the concentration of oxidized glutathione, samples were first normalized with $4 \mathrm{~N} \mathrm{NaOH}$ to $\mathrm{pH} 5.5-7.0$. Then, the fraction of reduced glutathione in the sample was quenched using 2-vinylpyridine (Sigma-Aldrich), followed by the measurement of total glutathione as described above. Total and oxidized glutathione tissue contents were expressed in micromoles per gram of total protein. The ratio of total to oxidized glutathione was calculated and used as a measure of antioxidant capacity.

\section{Statistical Analysis}

Data are expressed as means \pm SEM. Student's t test or MannWhitney analysis (depending on distribution of the data) were used to compare results between $\mathrm{O}_{2}$ and $\mathrm{O}_{2}+\mathrm{H}$ mice, between naïve and $\mathrm{NH}$ mice and between $\mathrm{O}_{2}$ and naïve groups. Values were considered significantly different if the $\mathrm{p}$ value was $\leq 0.05$.

\section{Results}

\section{Outcome of Hyperoxia-Induced BPD}

Weight. All mice had similar body weight at the start of the experiment (data not shown). Hyperoxic exposure resulted in a significantly decreased weight at the end of BPD modeling compared to naïve littermates $\left(\mathrm{O}_{2}\right.$ mice $6.22 \pm 0.3 \mathrm{~g}$ vs. naïve mice $10.6 \pm 1.3 \mathrm{~g} ; \mathrm{p}=0.004)$. Intermittent hypoxic stress in $\mathrm{O}_{2}+\mathrm{H}$ mice did not lead to a significant reduction in body weight gain $(5.9 \pm 0.8 \mathrm{~g}$; $\mathrm{p}=0.6)$ compared to their $\mathrm{O}_{2}$ counterparts. Normoxic mice exposed to intermittent hypoxic stress also demon- strated significantly decreased body weight (NH mice 7.6 $\pm 0.3 \mathrm{~g} ; \mathrm{p}=0.04$ ) compared to their naïve littermates.

Pulmonary Histopathology. Mice exposed to $65 \% \mathrm{O}_{2}$ for 4 weeks exhibited robust histological signs of alveolar developmental arrest, i.e. poor alveolar septation and enlarged terminal air sacks (fig. 1b, c). These hyperoxia-exposed mice demonstrated a significantly $(\mathrm{p}<0.0001)$ decreased RAC compared to that in normoxic animals (fig. 1b). However, $\mathrm{O}_{2}+\mathrm{H}$ mice subjected to intermittent hypoxic stress during hyperoxic exposure exhibited the lowest RAC, suggesting that hypoxic stress exacerbates the alveolar underdevelopment induced by hyperoxic exposure (fig. 1b). There was no difference in the degree of alveolarization between $\mathrm{NH}$ mice $(\mathrm{RAC}=12.02 \pm 0.54)$ and naïve mice $(\mathrm{RAC}=12.69 \pm 0.44$; fig. $1 \mathrm{~b})$.

\section{Inflammatory Changes in Lungs}

Immunohistochemical staining for Ly6G/C revealed significantly $(\mathrm{p}<0.0001)$ increased numbers of granulocytes in the lungs of $\mathrm{O}_{2}$ animals compared to those in naïve mice (fig. 2a). Intermittent hypoxic exposure in normoxic mice also resulted in a significantly $(\mathrm{p}=0.006)$ greater pulmonary granulocytic infiltration compared to that in naïve (normoxic) mice. When mice subjected to hyperoxia were compared to mice subjected to hyperoxia plus intermittent hypoxia, no difference in pulmonary granulocytic infiltration was detected (fig. 2a).

\section{Oxidative Lung Injury}

Mice exposed to isolated hyperoxia demonstrated significantly $(\mathrm{p}=0.04)$ elevated protein carbonyl content in their lung tissue compared to that in naïve mice (fig. 2b). The lung tissue level of oxidized glutathione was significantly increased in both $\mathrm{O}_{2}$ mice and $\mathrm{O}_{2}+\mathrm{H}$ mice compared to naïve mice (fig. 2c). However, in $\mathrm{O}_{2}$ mice, the elevation of oxidized glutathione content was paralleled by a significant elevation of the total glutathione level in lung tissue $(33.4 \pm 3.5 \mu \mathrm{mol} / \mathrm{g}$ protein; $\mathrm{p}=0.04) \mathrm{com}$ pared to naïve mice $(22.7 \pm 3.3 \mu \mathrm{mol} / \mathrm{g}$ protein). As a result, there was no difference in the total/oxidized pulmonary glutathione ratio (the marker of glutathione antioxidant capacity) in $\mathrm{O}_{2}$ mice compared to their naïve counterparts (fig. 2d). In contrast, in $\mathrm{O}_{2}+\mathrm{H}$ mice, a significant rise in the oxidized glutathione level was not associated with a significant rise in total glutathione content in their lung tissue (data not shown). Moreover, $\mathrm{O}_{2}+$ $\mathrm{H}$ mice demonstrated a significantly $(\mathrm{p}=0.04)$ higher level of oxidized glutathione compared to $\mathrm{O}_{2}$ animals (fig. $2 c)$. This resulted in a significant $(\mathrm{p}=0.02)$ reduction in the total/oxidized glutathione ratio compared to that 
Fig. 1. Schema of the study design (a), RAC (b) and pulmonary histopathology (c) in naïve $(\mathrm{N} ; \mathrm{n}=5), \mathrm{NH}(\mathrm{n}=10), \mathrm{O}_{2}(\mathrm{n}=10)$ and $\mathrm{O}_{2}+\mathrm{H}(\mathrm{n}=15)$ mice. $\mathbf{b}$ Data are means \pm SEM. ${ }^{a} \mathrm{p}<0.0001$ compared to $\mathrm{O}_{2}$ mice and ${ }^{\mathrm{b}} \mathrm{p}<0.0001$ compared to naïve mice. c Shown are $5-\mu \mathrm{m}$ frontal lung sections stained with hematoxylin and eosin. Magnification $\times 10$.
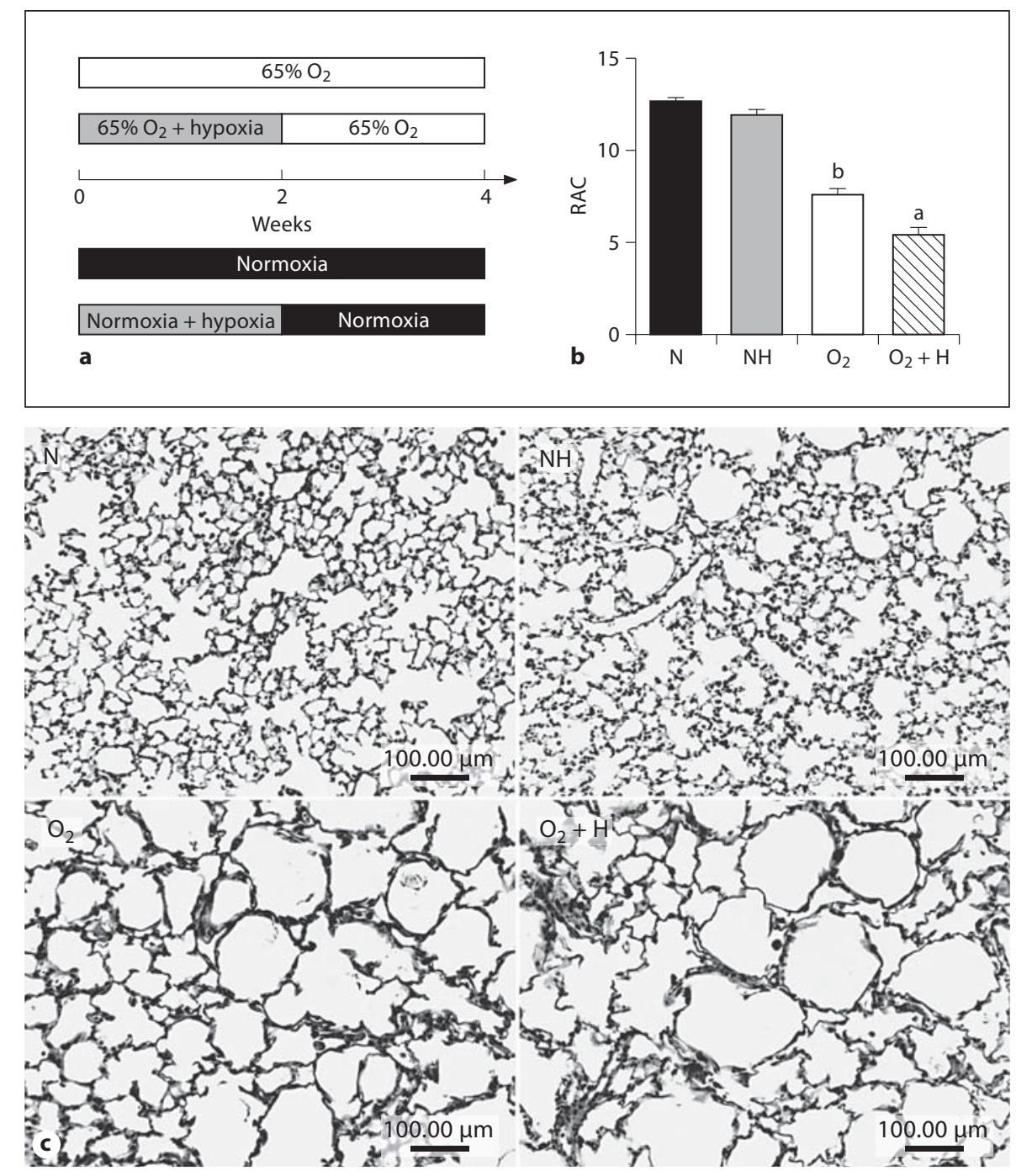

in mice exposed only to $\mathrm{O}_{2}$ (fig. 2d). This depletion of the glutathione antioxidant capacity in $\mathrm{O}_{2}+\mathrm{H}$ animals was associated with exacerbation of oxidative damage to pulmonary proteins, as the protein carbonyl content was substantially increased $(\mathrm{p}=0.05)$ compared to $\mathrm{O}_{2}$ mice (fig. 2b). There was no significant difference in pulmonary protein carbonyl content, total/oxidized glutathione ratio or the level of oxidized glutathione between $\mathrm{NH}$ and naïve mice (fig. $2 b-d$ ).

\section{Discussion}

There are 2 major findings of this study: (1) intermittent, brief hypoxic stress significantly exacerbates the degree of alveolar developmental arrest induced by hyper- oxic exposure in neonatal mice and (2) the mechanism of this exacerbation is linked to a significant amplification of oxidative lung injury.

Oxidative injury is a well-known mechanism for the development of BPD in human and animal neonates [5, 20]. It has been reported that exposure of the lungs to high oxygen concentrations results in the exhaustion of antioxidant systems and in a robust increase in products of lipid and protein peroxidation in pulmonary tissue [21, 22]. This is associated with severe alveolar developmental arrest in neonatal rats [23]. Our study using a neonatal murine model demonstrates that chronic hyperoxia exposure results in a significant elevation of protein carbonyls and oxidized glutathione content in lung tissue associated with a profound alveolar hypoplasia. Importantly, our experimental design is the first to highlight 
Fig. 2. The total number of Ly6G/C-immunopositive cells per square millimeter of pulmonary tissue (a), pulmonary protein carbonyl content (b), pulmonary oxidized glutathione content (c) and total/oxidized glutathione ratio (d) in naïve (black bars; $\mathrm{n}=5$ ), $\mathrm{NH}$ (gray bars; $\mathrm{n}=10$ ), $\mathrm{O}_{2}$ (white bars; $\mathrm{n}=10$ ) and $\mathrm{O}_{2}+\mathrm{H}$ (striped bars; $\mathrm{n}=15$ ) mice. Data are means \pm SEM. $\mathrm{a}^{\mathrm{a}} \mathrm{p}=0.006$ and ${ }^{\mathrm{b}} \mathrm{p}<0.0001$ compared to naïve mice. $\mathbf{b}{ }^{a} \mathrm{p}=0.05$ compared to $\mathrm{O}_{2}$ mice and ${ }^{\mathrm{b}} \mathrm{p}=0.04$ compared to naïve animals. $c^{a} \mathrm{p}=0.01$ compared to $\mathrm{O}_{2}$ mice and ${ }^{\mathrm{b}} \mathrm{p}=0.03$ compared to their naïve littermates. $\mathbf{d}^{\mathrm{a}} \mathrm{p}=0.04$ compared to $\mathrm{O}_{2}$ mice.

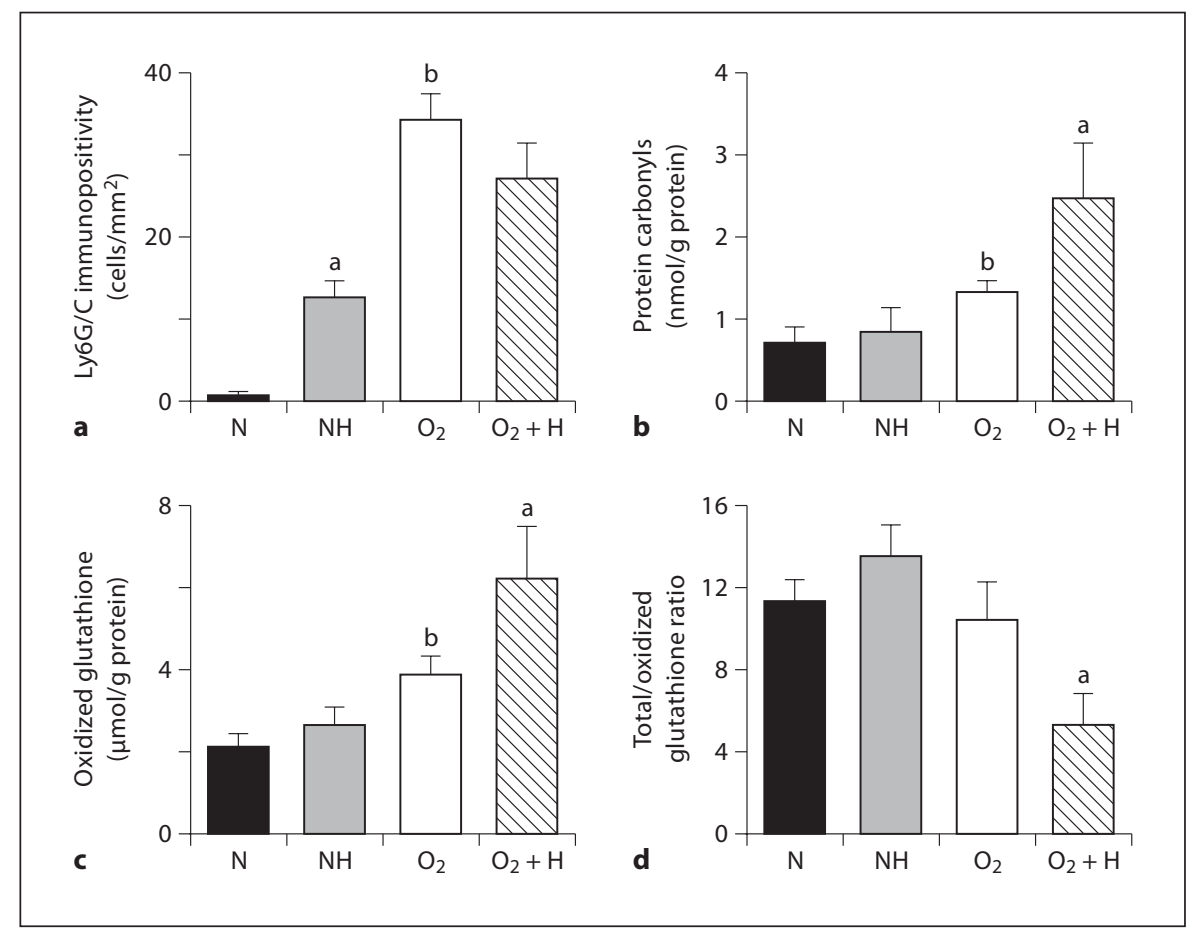

the critical role of intermittent hypoxic stress in the exacerbation of oxidative pulmonary injury in a mouse model of BPD. Mice that were subjected to the combination of intermittent hypoxia and hyperoxia developed the most severe oxidative lung injury and the most profound alveolar developmental arrest. Although mice subjected to isolated hyperoxia exhibited a significant increase in oxidized glutathione content in their lungs, the total/oxidized glutathione ratio did not differ from that in their naïve counterparts. This can be explained by the compensatory rise in the tissue pool of total glutathione in response to the oxidative stress load induced by chronic $\mathrm{O}_{2}$ exposure. It has been shown that the level of reduced glutathione increases in response to hyperoxia in lung tissue in rodents $[24,25]$ and in human alveolar epithelial cell culture [26]. Although the exact cellular mechanism for this phenomenon remains unknown, it has been suggested that the increase in gamma-glutamylcysteine synthase activity is responsible for the increase in intracellular glutathione during oxidative stress in alveolar epithelial cells [27]. As a result, the major marker of antioxidant capacity in the glutathione system (the total/oxidized glutathione ratio) remained unchanged. In contrast, mice subjected to the combination of hyperoxia and hypoxia exhibited the highest level of protein oxidation products associated with a failure to maintain a normal level of the total/oxidized glutathione ratio. This indicates an exhaustion of their glutathione antioxidant capacity. Thus, our data suggest that the severity of oxidative stress in lungs is potentiated by intermittent hypoxic episodes during hyperoxic exposure.

It is well documented that both isolated hypoxia and isolated hyperoxia induce severe oxidative stress [28]. However, there are no reports on pulmonary oxidative injury following exposure to intermittent hypoxia-hyperoxia. Interestingly, using a neonatal rat model of retinopathy of prematurity, Penn et al. [29] demonstrated that the extent of retinal damage increased linearly with the increase in the difference in the two oxygen concentrations to which a treatment group was subjected. York et al. [30] demonstrated that very-low-birth-weight infants experiencing fluctuating levels of partial pressure of arterial oxygen were at higher risk for threshold-stage retinopathy of prematurity compared to those neonates that had relatively constant levels of partial pressure of arterial oxygen.

Clinical observation indicates that in spite of continuous oxygen therapy, premature infants experience multiple episodes of hypoxemia $\left(\mathrm{O}_{2}\right.$ desaturations) associated with apnea of prematurity, patent ductus arteriosus and infections, among other causes. Recently, it has been shown that the treatment of apnea of prematurity with 
caffeine was strongly associated with a significant reduction in the incidence of BPD [31]. Moreover, several investigators have reported that infants who develop BPD experience more frequent episodes of $\mathrm{O}_{2}$ desaturations than those infants who recover from respiratory distress syndrome without developing BPD [10, 11]. Our experimental results suggest that the mechanistic link between frequent episodes of hypoxemia and the development of BPD observed in human neonates is exacerbation of oxidative lung injury triggered by the fluctuation in the fraction of inspired oxygen and oxygenation.

In our study, we did not determine the source of ROS. Although activated inflammatory cells (granulocytes) infiltrating lungs in BPD have been shown to produce ROS [32], our results indicate that it is unlikely that granulocytes are responsible for the exacerbation of oxidative injury in $\mathrm{O}_{2}+\mathrm{H}$ mice. The degree of pulmonary granulocyte infiltration in $\mathrm{O}_{2}+\mathrm{H}$ mice was similar to that in mice exposed to hyperoxia alone. In addition, significantly increased pulmonary infiltration with granulocytes in $\mathrm{NH}$ mice was not associated with the induction of oxidative lung injury. The potential source of ROS in our experiments might be pulmonary mitochondria. $\mathrm{Mi}$ tochondria are known to be the major site for the production of ROS in intact and stressed (postischemic, hyperoxia-exposed) tissue. It has been shown that following hyperoxic exposure, pulmonary endothelial cells significantly increase production of ROS originating from the mitochondrial electron chain $[33,34]$, and that glutathione reductase gene transfer to mitochondria significantly protected $\mathrm{H} 441$ cells against hyperoxia-induced growth arrest and improved the glutathione/oxidized glutathione ratio in hyperoxic cells [35]. Given that glutathione reductase is a key enzyme supporting intramitochondrial glutathione antioxidant capacity, these data suggest that the ROS of mitochondrial origin are involved in cellular growth arrest during hyperoxia [36].

In conclusion, our data demonstrate that intermittent hypoxic stress during hyperoxic induction of BPD in neonatal mice significantly exacerbates oxidative lung injury and alveolar developmental arrest. These results suggest that the aggressive prevention of hypoxic episodes in neonates at risk for the development of BPD should be considered a therapeutic target to attenuate the extent of oxidative lung injury.

\section{Acknowledgement}

We thank Dr. Casper Casperson for his expert advice in the establishment of the assay for the measurement of total and oxidized glutathione tissue content.

\section{References}

-1 Ehrenkranz RA, Walsh MC, Vohr BR, Jobe AH, Wright LL, Fanaroff AA, Wrage LA, Poole K; National Institutes of Child Health and Human Development Neonatal Research Network: Validation of the National Institutes of Health consensus definition of bronchopulmonary dysplasia. Pediatrics 2005;116:1353-1360.

2 Coalson JJ: Pathology of bronchopulmonary dysplasia. Semin Perinatol 2006;30:179184.

-3 Asikainen TM, White CW: Pulmonary antioxidant defenses in the preterm newborn with respiratory distress and bronchopulmonary dysplasia in evolution: implications for antioxidant therapy. Antioxid Redox Sig nal 2004;6:155-167.

4 Chess PR, D’Angio CT, Pryhuber GS, Maniscalco WM: Pathogenesis of bronchopulmonary dysplasia. Semin Perinatol 2006;30: 171-178.

5 Saugstad OD: Bronchopulmonary dysplasia - oxidative stress and antioxidants. Semin Neonatol 2003;8:39-49.
6 Jia L, Xu M, Zhen W, Shen X, Zhu Y, Wang W, Wang X: Novel anti-oxidative role of calreticulin in protecting A549 human type II alveolar epithelial cells against hypoxic injury. Am J Physiol Cell Physiol 2008;294: C47-C55.

7 Freeman BA, Topolosky MK, Crapo JD: Hyperoxia increases oxygen radical production in rat lung homogenates. Arch Biochem Biophys 1982;216:477-484.

${ }_{8}$ Njalsson R, Norgren S: Physiological and pathological aspects of GSH metabolism. Acta Paediatr 2005;94:132-137.

-9 Haworth SG, Hislop AA: Lung development - the effects of chronic hypoxia. Semin Neonatol 2003;8:1-8.

10 Garg M, Kurzner SI, Bautista DB, Keens TG: Clinically unsuspected hypoxia during sleep and feeding in infants with bronchopulmonary dysplasia. Pediatrics 1988;81:635-642.

-11 Singer L, Martin RJ, Hawkins SW, BensonSzekely LJ, Yamashita TS, Carlo WA: Oxygen desaturation complicates feeding in infants with bronchopulmonary dysplasia after discharge. Pediatrics 1992;90:380-384.
12 Fleckenstein K, Zgonjanin L, Chen L, Rabbani Z, Jackson IL, Thrasher B, Kirkpatrick J, Foster WM, Vujaskovic Z: Temporal onset of hypoxia and oxidative stress after pulmonary irradiation. Int J Radiat Oncol Biol Phys 2007;68:196-204.

-13 Semenza GL, Prabhakar NR: HIF-1-dependent respiratory, cardiovascular, and redox responses to chronic intermittent hypoxia. Antioxid Redox Signal 2007;9:1391-1396.

14 Ratner V, Kishkurno SV, Slinko SK, Sosunov SA, Sosunov AA, Polin RA, Ten VS: The contribution of intermittent hypoxemia to late neurological handicap in mice with hyperoxia-induced lung injury. Neonatology 2007; 92:50-58

15 Warburton D, Schwarz M, Tefft D, FloresDelgado G, Anderson KD, Cardoso WV: The molecular basis of lung morphogenesis. Mech Dev 2000;92:55-81.

16 Cooney TP, Thurlbeck WM: The radial alveolar count method of Emery and Mithal: a reappraisal 1 - postnatal lung growth. Tho$\operatorname{rax} 1982 ; 37: 572-579$ 
-17 Zeltner TB, Caduff JH, Gehr P, Pfenninger J, Burri PH: The postnatal development and growth of the human lung. I. Morphometry. Respir Physiol 1987;67:247-267.

-18 Bradford MM: A rapid and sensitive method for the quantitation of microgram quantities of protein utilizing the principle of proteindye binding. Anal Biochem 1976;72:248254.

19 Griffith OW: Determination of glutathione and glutathione disulfide using glutathione reductase and 2-vinylpyridine. Anal Biochem 1980;106:207-212.

-20 Bucher JR, Roberts RJ: The development of the newborn rat lung in hyperoxia: a doseresponse study of lung growth, maturation, and changes in antioxidant enzyme activities. Pediatr Res 1981;15:999-1008.

-21 Vento G, Mele MC, Mordente A, Romagnoli C, Matassa PG, Zecca E, Zappacosta B, Persichilli S: High total antioxidant activity and uric acid in tracheobronchial aspirate fluid of preterm infants during oxidative stress: an adaptive response to hyperoxia? Acta Paediatr 2000;89:336-342.

22 Gladstone IM Jr, Levine RL: Oxidation of proteins in neonatal lungs. Pediatrics 1994; 93:764-768.

-23 Dauger S, Ferkdadji L, Saumon G, Vardon G, Peuchmaur M, Gaultier C, Gallego J: Neonatal exposure to $65 \%$ oxygen durably impairs lung architecture and breathing pattern in adult mice. Chest 2003;123:530-538.
-24 Lee ES, Smith WE, Quach HT, Jones BD, Santilli SM, Vatassery GT: Moderate hyperoxia (40\%) increases antioxidant levels in mouse tissue. J Surg Res 2005;127:80-84.

25 Barrios R, Shi ZZ, Kala SV, Wiseman AL, Welty SE, Kala G, Bahler AA, Ou CN, Lieberman MW: Oxygen-induced pulmonary injury in gamma-glutamyl transpeptidase-deficient mice. Lung 2001;179:319330.

26 Koo HC, Davis JM, Li Y, Hatzis D, Opsimos H, Pollack S, Strayer MS, Ballard PL, Kazzaz JA: Effects of transgene expression of superoxide dismutase and glutathione peroxidase on pulmonary epithelial cell growth in hyperoxia. Am J Physiol Lung Cell Mol Physiol 2005;288:L718-L726.

27 Rahman I, Bel A, Mulier B, Donaldson K, MacNee W: Differential regulation of glutathione by oxidants and dexamethasone in alveolar epithelial cells. Am J Physiol 1998;275: L80-L86.

28 Davis JM: Role of oxidant injury in the pathogenesis of neonatal lung disease. Acta Paediatr Suppl 2002;91:23-25.

29 Penn JS, Henry MM, Wall PT, Tolman BL: The range of $\mathrm{PaO}_{2}$ variation determines the severity of oxygen-induced retinopathy in newborn rats. Invest Ophthalmol Vis Sci 1995;36:2063-2070.

30 York JR, Landers S, Kirby RS, Arbogast PG, Penn JS: Arterial oxygen fluctuation and retinopathy of prematurity in very-low-birthweight infants. J Perinatol 2004;24:82-87.
1 Schmidt B, Roberts RS, Davis P, Doyle LW, Barrington KJ, Ohlsson A, Solimano A, Tin W: Caffeine therapy for apnea of prematurity. N Engl J Med 2006;354:2112-2121.

32 Buss IH, Darlow BA, Winterbourn CC: Elevated protein carbonyls and lipid peroxidation products correlating with myeloperoxidase in tracheal aspirates from premature infants. Pediatr Res 2000;47:640-645.

-33 Brueckl C, Kaestle S, Kerem A, Habazettl H, Krombach F, Kuppe H, Kuebler WM: Hyperoxia-induced reactive oxygen species formation in pulmonary capillary endothelial cells in situ. Am J Respir Cell Mol Biol 2006;34: 453-463.

34 Freeman BA, Crapo JD: Hyperoxia increases oxygen radical production in rat lungs and lung mitochondria. J Biol Chem 1981;256: 10986-10992.

35 O'Donovan DJ, Katkin JP, Tamura T, Smith CV, Welty SE: Attenuation of hyperoxia-induced growth inhibition in H441 cells by gene transfer of mitochondrially targeted glutathione reductase. Am J Respir Cell Mol Biol 2000;22:732-738.

36 O'Donovan DJ, Fernandes CJ: Mitochondrial glutathione and oxidative stress: implications for pulmonary oxygen toxicity in premature infants. Mol Genet Metab 2000;71: 352-358. 